ORIGINAL ARTICLE

\title{
Relationships Between Emotional Intelligence, Mental Skills and Techniques: A Research on Professional Athletes
}

\author{
TEMEL CAKIROĞLU1 \\ ${ }^{1}$ Lokman Hekim University, Faculty of Sports Sciences \\ Correspondence email: tmlckroglu@gmail.com
}

\begin{abstract}
The purpose of this research is to examine the relationships between the levels of mental skills and techniques of university students, who continue their sports life as licensed in different sports branches, and the emotional intelligence in sports. A total of 169 athletes, 91 male $(53.8 \%)$ (Mage=25.36 \pm 6.06$)$ and 78 female (46.2\%) $\left(\mathrm{M}_{\mathrm{age}}=23.03 \pm 4.98\right)$, who continue their professional sports life in different sports branches, voluntarily participated in the research. The research was designed in relational screening model. Personal Information Form, Mental Training Inventory in Sport, and Emotional Intelligence Inventory in Sport, which were created by the researchers, were used as data collection tools within the scope of the research. In the analysis of the data, firstly, the skewness and kurtosis values were checked for the normality assumptions and it was determined that the distribution was normal. In this direction, t-test was used to compare two independent groups, Pearson correlation analysis was used to determine the relationships between the variables, and multiple linear regression analysis was used to determine the power of the independent variables in predicting the dependent variable. When the findings obtained within the scope of the research were examined, it was determined that the emotional intelligence sub-dimensions significantly predicted the components of mental training skills and techniques. In this context, a result was obtained that as the level of emotional intelligence increases, the levels of mental training skills and techniques will also increase. However, when the analyzes for demographic variables were examined within the scope of the research, it was determined that there was a significant difference within the groups. As a result, it is recommended to include programs on emotional intelligence and mental training skills and techniques in the training of athletes in order to achieve the optimal range of sportive performance.
\end{abstract}

Keywords: Emotional Intelligence, Mental Training, Sports

\section{INTRODUCTION}

In addition to physical preparation, mental training and development of emotional intelligence are also important for athlete performance. In order to achieve success in sports, along with physical training, it is a necessity for athletes to be mentally good and to have appropriate mental training techniques. Athletes' mental skill levels and emotional structures affect their performance levels (Arı et al., 2020; Kahrovic et al., 2014; Patrick, 1995; Erhan et al., 2015; Yarayan \& Ayan, 2018; Yarayan Yıldız \& Gülşen 2018). This reveals the importance of mental basic skills, mental performance skills, interpersonal skills, self-talk, imagery, regulation of own emotions, and use of social skills and emotions, which exist in athletes, on the road to success (Yarayan \&illhan, 2018; Lane et al., 2009; Amasiatu, 2013; Slimani, Tod, Chaabene, Miarka \& Chamari, 2016).

Mental training is a concept that aims to improve and strengthen the psychological state of athletes through their mental skills and has techniques in this direction (Weinberg \& Gould, 2014). Making preparations by imagery without involving any physical activity, despite the psychological processes experienced by the athletes during the competition and the positive or negative situations that may be encountered, is an essential part of the mental training (Koruç \& Bayar, 1990). Mental skill and mental technique are essential components of the mental training concept. While mental skills are defined as special processes that enable to increase concentration in sports, improve the quality of training or overcome stress; mental techniques are expressed as the preferred mental training methods to improve athlete performance (Behnke, Tomczak, Kaczmarek, Komar \& Gracz, 2017).

It is thought that athletes contribute positively to their development by using techniques such as cognitive strategy, goal setting, self-talk, relaxation, motivation and emotional regulation (Sachs, 1991). It is stated that handling self-talk and mental skills together has a positive effect on the performance of athletes (Kolovelonis, Goudas, Hassandra \& Dermitzaki, 2012). Athletes can contribute to increasing their motivation with positive self-talk before or during the competition. There are studies in the literature showing that success in sports is related to mental skills and emotional intelligence (Sarıkabak, 2020; Mizuguchi, Nakata, Uchida \& Kanosuel, 2012; Slimani, Tod, Chaabene, Miarka \& Chamari, 2016; Kulak, Kerkez \& Aktaş, 2011; Bahadır \& Adiloğlulları, 2020).

The concept of emotional intelligence was first discussed by psychologist Peter Salovey and psychologist John Mayer in 1990 and was defined as the use of feelings to guide thought and action as a result of observing one's own and other people's feelings (Salovey \& Mayer, 1990). Different from this definition, emotional intelligence has been defined by many researchers who deal with different aspects of emotional intelligence. While some researchers consider emotional intelligence as the ability to express emotions effectively by understanding them in a real sense (Law, Wong \& Song, 2004), some researchers, on the other hand, state emotional intelligence as a type of intelligence that affects the working process and performance (Cooper \& Sawaf, 1997; Gates, 1995; Goleman, 1995; Sosik \& Megerian, 1999). It is seen that emotional intelligence, which is often discussed with the variables of job performance, job satisfaction and burnout 
in the literature (Gürbüz \& Yüksel 2008; Güllüce \& İşcen 2010), has been the subject of sports-related researches in recent years (Sarıkabak, 2020). It is a necessity for athletes to take precautions against problems that may affect the person emotionally, such as pressure, stress, anxiety, as well as their physical performance on the road to success. This situation reveals the importance of researches on the subject.

Sports can be defined as physiologically and psychologically analyzing oneself, his/her opponent and his/her branch, understanding and recognizing all necessary features and managing these processes professionally (Sarıkabak, 2020). Mental training is an important tool in terms of sports psychology for the mental, emotional and behavioral development of athletes and for solving the problems that arise in this development (Loehr, 1995). Our emotions, on the other hand, are stimuli that enable us to act. This indicates that there is a relationship between mental skill and emotional intelligence. Athlete students can use the knowledge they have learned through their experiences and achievements throughout their professional lives as trainers or coaches after graduation. In addition, these people need emotional and cognitive experiences in order to be successful in their active sports lives and when they work as trainers (Sarıkabak, 2020).

In Turkey, there is not much research on mental skills and technique in sports and emotional intelligence in sports. This situation prompted and motivated us to do this research. In this context, within the scope of the research, it is aimed to contribute to the literature by examining the relationships between the levels of mental skills and techniques of university students who continue their sports life as licensed in different sports branches and the emotional intelligence in sports.

\section{METHOD}

Research Model: In this research, which was designed in a relational screening model, the relationships between the levels of mental skills and techniques of university students who continue their sports life as licensed in different sports branches (football, basketball, and handball) and the emotional intelligence in sports were examined. "In this model, it is aimed to determine the existence and/or degree of co-variance between two or more variables (Fraenkel, Wallen \& Hyun, 2012; Creswell \& Creswell, 2017)." The model created within the scope of the research is presented in Figure 1.

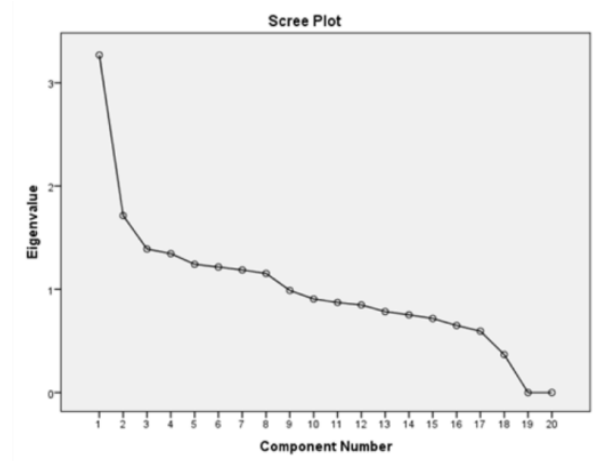

Figure 1. Model of the Research
Research Group: Participants were selected by the convenience sampling method, taking into account easy accessibility and affordability (Gravetter \& Forzano, 2012). In this context, a total of 169 athletes, 91 male $(53,8 \%)$ $\left(M_{\text {age }}=25,36 \pm 6,06\right)$ and 78 female $(46,2 \%)$ $\left(M_{a g e}=23,03 \pm 4,98\right)$, who continue their professional sports life in different sports branches, voluntarily participated in the research. In addition, the average years of playing sports for male participants was determined as $\left(M_{\text {year }}=8.51 \pm 5.74\right)$ and for female participants as $\left(M_{y e a r}=6.47 \pm 3.98\right)$.

\section{Data Collection Tools}

Personal Information Form: It consists of questions containing demographic information about the gender, age and years of playing sports of the students included in the research.

Mental Training Inventory in Sport: The inventory, which aims to measure mental skills and mental techniques used in mental training practices, was developed by Behnke et al. (2017). The Turkish adaptation of the inventory was made by Yarayan \& İlhan (2018). The inventory consists of 5 sub-dimensions and a total of 20 items as Mental Basic Skills (4 items) $(\alpha=0.82)$, Mental Performance Skills (6 items) $(\alpha=0.82)$, Interpersonal Skills (4 items) $(\alpha=0.85)$, Self-Talk (3 items) $(\alpha=0.91)$, and Imagery (3 items) $(\alpha=0.82)$. The inventory, which has a 5-point Likert type structure, is scored as (1) "I totally disagree" and (5) "I totally agree". In addition, the inventory also gives a total point. There is no reverse coded item in the inventory. As a result of the confirmatory factor analysis for the construct validity of the inventory, the fit index values were calculated as $\mathrm{x}^{2 / \mathrm{df}}=1,85, \mathrm{RMSEA}=.053, \quad \mathrm{SRMR}=.048, \quad \mathrm{RMR}=.34$, $\mathrm{NFI}=.91, \mathrm{AGFI}=.88, \mathrm{CFI}=.95, \mathrm{GFI}=.91$. In this research, the Cronbach's Alpha internal consistency coefficient for the overall inventory was determined as $(\alpha=0.94)$.

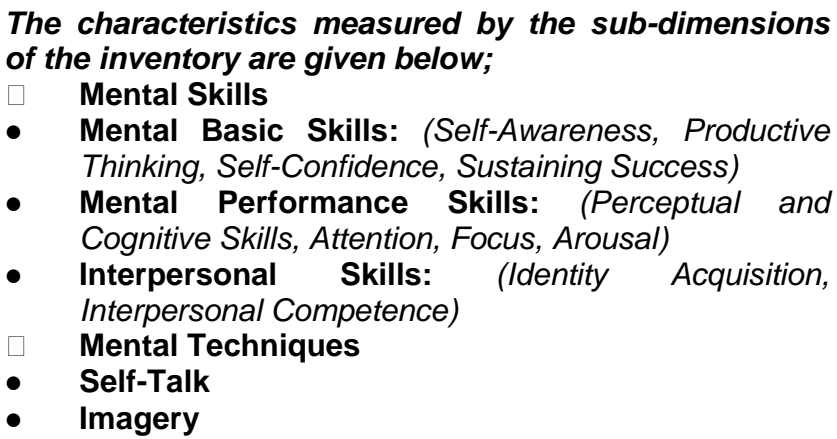

Emotional Intelligence Inventory in Sport: Based on the Emotional Intelligence Inventory (Emotional Intelligence Scale) developed by Shutte et al. (1998), it was adapted for the athlete population by Lane et al. (2009) to measure the emotional intelligence abilities of athletes. The Turkish adaptation of the inventory was made by Adiloğulları \& Görgülü (2015). The inventory consists of 5 subdimensions and a total of 18 items as Evaluating Others' Emotions (4 items) ( $\alpha=0.69)$, Evaluating One's Own Emotions ( 3 items) $(\alpha=0.85)$, Emotion Regulation (2 items) $(\alpha=0.67)$, Social Skills (3 items) $(\alpha=0.61)$, and Use of Emotions (6 items) $(\alpha=0.85)$. The inventory, which has a 5- 
point Likert type structure, is scored as (1) "I Totally Disagree" and (5) "I Totally Agree". In addition, the inventory also gives a total point. There is no reverse coded item in the inventory. As a result of the confirmatory factor analysis for the construct validity of the inventory, the fit index values were calculated as $x^{2 / d f}=2,36$, RMSEA $=.054, \mathrm{NFI}=.92, \mathrm{CFI}=.95$. (Adiloğulları \& Görgülü, 2015). In this study, the Cronbach's Alpha internal consistency coefficient for the overall inventory was determined as $(\alpha=0.89)$.

Analysis and Interpretation of Data: Microsoft Excel and SPSS 22.0 computer program were used for the statistical analysis of the data obtained from the inventories. In the research, firstly, empty data were evaluated for the appropriateness of the analyzes and the control of the assumptions. As a result of this process, the data of 3 participants who filled in incorrectly and incompletely were excluded from the analysis.

After this stage, the normality assumptions were first checked with the Kolmogorov-Smirnov test and it was determined that the data did not meet the normality assumptions. However, there is an increasing number of views in the related literature that normality tests are not sufficient in Likert-type scales (Tabachnick \& Fidell, 2013; Hair et al. 2013). For this reason, the prominent skewness and kurtosis values were examined for the normality assumptions. In this context, the $-1.5+1.5$ skewness kurtosis values suggested by Tabachnick \& Fidell (2013) were taken into consideration and the distribution was found to be normal (Table 1). In this direction, T-Test was used to determine the differences between individuals' mental skills and techniques and emotional intelligence levels by the gender variable. For the T-Test, values related to the level of being affected by the differences between the means of the significant difference obtained as a result of Cohen's $d$ analysis were calculated. If these values are .20, they are accepted as "low", if .50 as "moderate", and if .80 as "high" (Cohen, 1988). In addition, within the scope of the research, Pearson Product-Moment Correlation analysis was used to determine the relationships between the variables, and Multiple Linear Regression analysis was used to determine the power of the independent variable (Emotional Intelligence SubDimensions) in predicting the dependent variable (Mental Training Skills and Techniques Total Point).

Within the scope of the research, the regression assumption criteria were examined. In this direction, extreme value analyzes were evaluated. As a result of the extreme value analysis, the data of 3 more people were excluded from the analysis. Büyüköztürk (2012) states that the correlation value between the variables included in the model should be below .80, the variance inflation factor (VIF) should be below 10 and the Durbin-Watson value should be below 0.2 . Within the scope of the research, the relevant assumptions were examined and it was determined that there was no multicollinearity problem in this context.

\section{RESULTS}

Table 1. Average, Standard Deviation, Skewness and Kurtosis Values of Inventories Used in the Scope of the Research

\begin{tabular}{|l|l|l|l|l|l|l|}
\hline Scales & Sub-Dimensions & N & $\square$ & Ss & Skewness & Kurtosis \\
\hline Emotional Intelligence Inventory & EOE & 169 & 16,6450 & 2,55732 &,- 336 &,- 660 \\
\cline { 2 - 7 } & EOE2 & 169 & 12,9527 & 1,73826 &,- 346 &,- 914 \\
\cline { 2 - 7 } & RR & 169 & 8,4201 & 1,30742 &,- 769 &, 888 \\
\cline { 2 - 7 } & SS & 169 & 12,3550 & 2,18040 &,- 757 &, 214 \\
\cline { 2 - 7 } & UE & 169 & 25,5385 & 3,46582 &,- 519 &,- 067 \\
\hline Mental Training Inventory & MT Total Points & 169 & 82,5444 & 12,21775 &,- 666 &, 314 \\
\hline
\end{tabular}

In Table 1, it is seen that the skewness values are between -,769 and -,336 and the kurtosis values are between -,914 and ,888. Considering the $-1.5+1.5$ skewness kurtosis values suggested by Tabachnick \& Fidell (2013), the distribution was found to be normal.

\section{Results Regarding the Responses to the Inventories in terms of Demographic Variables}

Table 2. T-Test Results of Mental Training Inventory by Gender Variable

\begin{tabular}{|c|c|c|c|c|c|c|c|c|}
\hline Sub-Dimensions & Gender & $\mathrm{N}$ & $\square$ & Ss & t & df & $\mathrm{p}$ & Cohen d \\
\hline \multirow[t]{2}{*}{ Mental Basic Skills } & Male & 91 & 16,6703 & 2,67937 &, 167 & 167 &, 868 & \\
\hline & Female & 78 & 16,6026 & 2,57026 & & & & \\
\hline \multirow[t]{2}{*}{ Mental Performance Skills } & Male & 91 & 24,6813 & 3,97179 & 1,332 & 167 &, 185 & \\
\hline & Female & 78 & 23,7692 & 4,92785 & & & & \\
\hline \multirow[t]{2}{*}{ Interpersonal Skills } & Male & 91 & 16,9670 & 2,69341 &,- 354 & 167 &, 723 & \\
\hline & Female & 78 & 17,1154 & 2,73496 & & & & \\
\hline \multirow[t]{2}{*}{ Self-Talk } & Male & 91 & 12,3407 & 2,06677 & 1,314 & 167 &, 190 & \\
\hline & Female & 78 & 11,8590 & 2,69065 & & & & \\
\hline \multirow[t]{2}{*}{ Imagery } & Male & 91 & 12,6703 & 1,86223 & 1,134 & 167 & ,258 & \\
\hline & Female & 78 & 12,2821 & 2,57307 & & & & \\
\hline \multirow[t]{2}{*}{ ZA-Total } & Male & 91 & 83,3297 & 11,36374 & ,902 & 167 & ,368 & \\
\hline & Female & 78 & 81,6282 & 13,15947 & & & & \\
\hline
\end{tabular}


Table 3. Correlation Analysis Results of Mental Training Inventory by Years of Playing Sports Variable

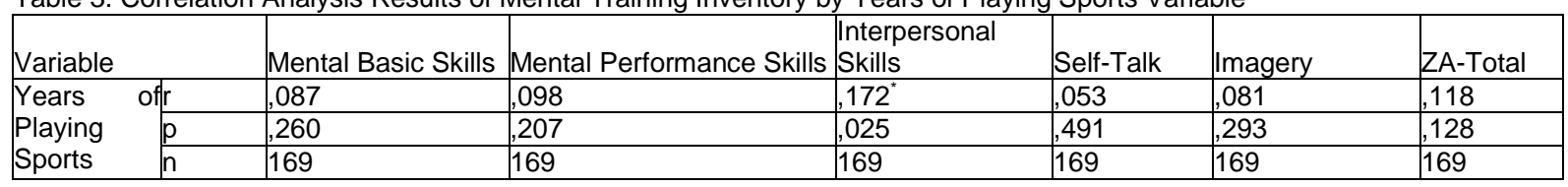

Table 4. T-Test Results of Emotional Intelligence Inventory by Gender Variable

\begin{tabular}{|c|c|c|c|c|c|c|c|c|}
\hline Sub-Dimensions & Gender & $\mathrm{N}$ & $\square$ & Ss & t & $d f$ & $p$ & Cohen d \\
\hline \multirow[t]{2}{*}{ BDD } & Male & 91 & 16,3626 & 2,56262 & $-1,557$ & 167 & 121 & \\
\hline & Female & 78 & 16,9744 & 2,52764 & & & & \\
\hline \multirow[t]{2}{*}{ KDD } & Male & 91 & 12,8462 & 1,80076 &,- 860 & 167 & 391 & \\
\hline & Female & 78 & 13,0769 & 1,66530 & & & & \\
\hline \multirow[t]{2}{*}{ DD } & Male & 91 & 8,5495 & 1,24957 & 1,393 & 167 &, 166 & \\
\hline & Female & 78 & 8,2692 & 1,36442 & & & & \\
\hline \multirow[t]{2}{*}{ SB } & Male & 91 & 12,4505 & 2,09371 & 614 & 167 &, 540 & \\
\hline & Female & 78 & 12,2436 & 2,28596 & & & & \\
\hline \multirow[t]{2}{*}{ DK } & Male & 91 & 25,4505 & 3,14206 &,- 355 & 167 & ,723 & \\
\hline & Female & 78 & 25,6410 & 3,82736 & & & & \\
\hline \multirow[t]{2}{*}{ DZ-Total } & Male & 91 & 75,6593 & 8,50388 &,- 404 & 167 & 687 & \\
\hline & Female & 78 & 76,2051 & 9,05733 & & & & \\
\hline
\end{tabular}

Table 5. Correlation Analysis Results of Emotional Intelligence Inventory by Years of Playing Sports Variable

\begin{tabular}{|c|c|c|c|c|c|c|}
\hline \multirow{2}{*}{\begin{tabular}{|l|} 
Variable \\
Years of Playing|r
\end{tabular}} & EOE1 & EOE2 & RR & SS & UE & El-Total \\
\hline &,- 031 &,- 112 & 126 & $175^{\star}$ & $167^{*}$ & ,097 \\
\hline Sports & ,693 & 145 & 1,104 & ,023 & ,030 & ,209 \\
\hline r & 169 & 169 & 169 & 169 & 169 & 169 \\
\hline
\end{tabular}

In Table 2, when the levels of mental training skills and techniques of the participants were examined by the gender variable, it was determined that there was no statistically significant difference in the mental basic skills $\left(t_{(167)}=167, p>.05\right)$, the mental performance skills $\left(t_{(167)}=1,332, p>.05\right)$, the interpersonal skills $\left(t_{(167)}=-, 354\right.$, $p>.05)$, the self-talk $\left(t_{(167)}=1,314, p>.05\right)$, the imagery $\left(t_{(167)}=1,134, p>.05\right)$, and the total points $\left(t_{(167)}=, 902, p>.05\right)$.

In Table 3, when the correlation analysis results between the years of playing sports and the levels of mental training skills and techniques of the participants were examined, it was seen that although there was a low level of positive correlation between the years of playing sports and the mental basic skills $(r=, 087 ; p>0,05)$, low level of positive correlation with the mental performance skills $(r=, 098 ; p>0,05)$, low level of positive correlation with the self-talk $(r=, 053 ; p>0,05)$ low level of positive correlation with the Imagery $(r=, 081 ; p>0,05)$, and low level of positive correlation with the total points $(r=, 118 ; p>0,05)$; it was determined that this correlation was not statistically significant. However, it was determined that there was a low level of positive correlation between the years of playing sports and interpersonal skills $(r=.172 ; p<0.05)$ and that this correlation was statistically significant. This result can be interpreted as the interpersonal skills (Identity Acquisition, Interpersonal Competence) of the participants will increase as the years of playing sports increase.

In Table 4, when the emotional intelligence levels of the participants were examined by gender variable, it was determined that there was no statistically significant difference in bdd $\left(t_{(167)}=-1,557, p>.05\right)$, kdd $\left(t_{(167)}=-, 860\right.$, $p>.05)$, dd $\left(t_{(167)}=1,393, p>.05\right)$, sb $\left(t_{(167)}=, 614, p>.05\right)$, dk $\left(t_{(167)}=-, 355 p>.05\right)$ and total points $\left(t_{(167)}=-, 404, p>.05\right)$.

In Table 5, when the correlation analysis results between the years of playing sports of the participants and the emotional intelligence were examined, although there was low level of negative correlation between the years of playing sports and bdd $(r=-, 031 ; p>0,05)$, low level of negative correlation with $k d d(r=-, 112 ; p>0,05)$, low level of positive correlation with dd $(r=, 126 ; p>0,05)$, and low level of positive correlation with the total point $(r=, 097 ; p>0,05)$, it was determined that this correlation was not statistically significant. On the other hand, it was determined that there was a low level of positive correlation between the years of playing sports and $\mathrm{sb}(\mathrm{r}=, 175 ; \mathrm{p}<0,05)$, and low level of positive correlation with $\mathrm{dk}(\mathrm{r}=, 167 ; \mathrm{p}<0,05)$, and that this correlation is statistically significant. This result can be interpreted as the level of use of social skills and emotions of the participants will increase as the years of playing sports increase.

Results of Regression Analysis: During the analysis of the data, Pearson Product-Moment Correlation analysis was conducted first of all, in order to test the relationships between the predictive variables, "Emotional Intelligence Sub-Dimensions" and the predicted variable, "Mental Training Skills and Techniques Total Point" of the research. Relationships between the variables are given in Table 6.

In Table 6, when the correlation analysis results between the emotional intelligence and the mental training skills and techniques of the participants were examined, it was determined that there was a moderate level of positive correlation between EOE1 and MT total point $(r=, 534$; $\mathrm{p}<0,05)$ moderate level of positive correlation with EOE2 $(r=, 569 ; p<0,05)$ moderate level of positive correlation with $\mathrm{RR}(\mathrm{r}=, 625 ; \mathrm{p}<0,05)$ moderate level of positive correlation with SS $(r=465 ; p<0,05)$, and high level of positive correlation with UE $(r=, 752 ; p<0,05)$ and that this correlation was statistically significant. After the relationships between the variables were determined, multiple regression analysis was made and the results are given in Table 7. 
It is seen that the multiple linear regression model established in Table 7 is significant. In this context, when the results of the analysis are examined, it is seen that the levels of mental training skills and techniques of the participants are not significantly predicted by the EO21, EOE2 and SS sub-dimensions. In addition, it is determined that RR and UE sub-dimensions significantly predicted the levels of mental training skills and techniques of the athletes and explained approximately $65 \%$ of the variance $\left(R=, 808, R^{2}=, 652, p<0,05\right)$. In line with this result, it can be said that the emotion regulation and the use of emotions are determinants of mental training skills and techniques.

In addition, when beta coefficients were examined as a result of multiple regression analysis, the standardized regression coefficient $(\beta)$ of the dd sub-dimension was found to be .274 , and the standardized regression coefficient $(\beta)$ of the $\mathrm{dk}$ sub-dimension was .486 . This result can be interpreted as the levels of mental training skills and techniques will also increase as the emotion regulation and the control of emotions increase.
Table 6. Correlation Analysis Results of the Relationship Between Emotional Intelligence and Mental Training Skills and Techniques

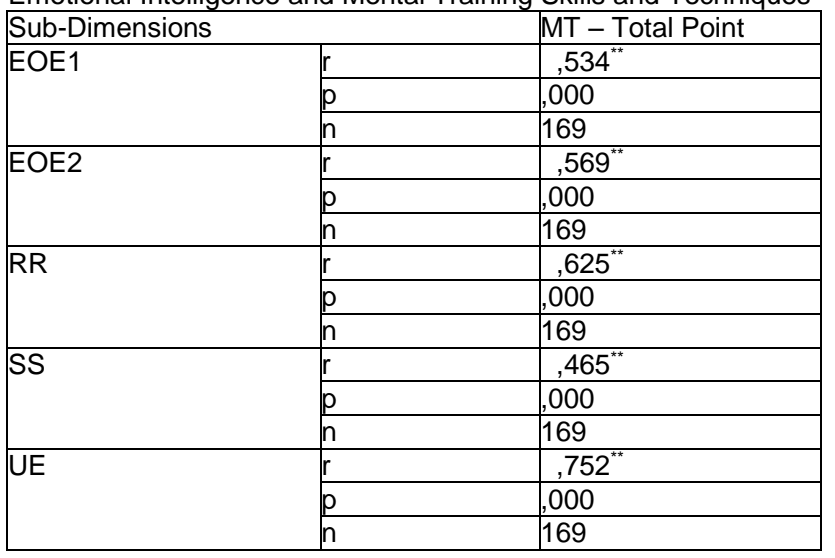

Table 7. Multiple Linear Regression Analysis Results on the Prediction of Mental Training Skills and Techniques by Emotional Intelligence Level

\begin{tabular}{|l|l|l|l|l|l|l|l|}
\hline Predictive Variables & $\mathrm{B}$ & Std. Error & Beta & $\mathrm{t}$ & $\mathrm{p}$ & Tolerance & VIF \\
\hline (Fixed) &,- 552 & 5,066 & &,- 109 &, 913 & & \\
\hline EOE1 &, 498 &, 279 &, 104 & 1,786 &, 076 &, 626 & 1,597 \\
EOE2 &, 677 &, 433 &, 096 & 1,561 &, 120 &, 561 & 1,782 \\
RR & 2,557 &, 541 &, 274 & 4,731 &, $000^{*}$ &, 638 & 1,568 \\
SS &, 062 &, 326 &, 011 &, 191 &, 849 &, 629 & 1,591 \\
UE & 1,713 &, 251 &, 486 & 6,837 &, $000^{*}$ &, 423 & 2,367 \\
\hline$R=, 808 ; R^{2}=, 652 ; F_{(5-168)}=61,125 ;$ Durbin-Watson=1,917; $\mathrm{p}<, 000$ & & & \\
\hline
\end{tabular}

\section{DISCUSSION}

Within the scope of the research, it was aimed to examine the levels of mental training skills and techniques and the levels of emotional intelligence in sport of university students who continue their sports life as licensed in different sports branches. A total of 169 athletes, 91 male $(53.8 \%)$ and 78 female $(46.2 \%)$, who continue their professional sports life in different sports branches, voluntarily participated in the research.

Discussion on the Gender Variable: It was determined that there was no statistically significant difference between the levels of mental training skills and techniques of the participants and the gender variable, in the sub-dimensions of mental basic skills, mental performance skills, interpersonal skills, self-talk, imagery, and in the total point. In the findings of research in which the mental training levels of the athletes studying at the faculty of sports sciences were examined by Erdoğan \& Gülşen (2020), there is no statistically significant difference by gender variable. Hardy et al. (2005) found that there was no significant difference between the levels of self-talk by the gender variable in the research results. According to the results of another research, it was determined that there was no significant difference between the gender of the participants and the variables of their communication skills. (Koçyiğit, Koçyiğit \& Özsoy, 2018). According to the results of the research on the mental skill levels of skiers, it was determined that there was no significant difference between the mental skill averages of female and male skiers (Azimkhani, 2014).
According to the findings of the research conducted by Sarıkabak (2020) with students who play sports, it was seen that there was a significant difference between the mental skills of the athletes and the gender variable only in the sub-dimension of stress reactions. While a significant difference was found in favor of male in the sub-dimension of mental performance skills in another research (Çelik \& Güngör), in the study of Nicholls, Polman, Levy, \& Backhouse (2009) with athletes, it was seen that a result was obtained in favor of male participants. According to the findings of the research conducted by Gülşen, Yıldız, Bayköse \& Eryücel (2018), a statistically significant difference was found between male and female in cognitive self-talk, motivational self-talk and self-talk levels. As a result of this finding, it was determined that the self-talk levels of male athletes in the sub-dimensions of self-talk were higher than female. In another study, it was determined that the average points of both motivational and cognitive function dimensions of self-talk status of female martial athletes were significantly higher than the males' points (Güvendi \& Pehlivan, 2020).

In another result of our research, the relationship between the years of playing sports and the levels of mental training skills and techniques of the participants was examined, and it was determined that there was a low level of positive correlation between the years of playing sports and the interpersonal skills, and this correlation was statistically significant. This situation makes it possible to interpret that as the years of playing sports of the athletes increase, their interpersonal skills will be positively affected 
and increased. Studies have found that there is a positive and significant relationship between sports age and interpersonal skills (Çelik \& Güngör, 2020; Erdoğan \& Gülşen, 2020). In the study conducted by Sarıkabak (2020), it is seen that as the sports year increases, the level of evaluating mental skills will also increase. In another research, it was seen that there were significant differences between the years of playing sports and the mental skills of individuals (Güler, 2015). According to the finding obtained from another study, it was determined that the mental training levels of the athletes who have more years of playing volleyball are at a higher level (Kara \& Hoşver, 2019).

When the emotional intelligence levels of the participants were examined by the gender variable, it was determined that there was no statistically significant difference in the sub-dimensions of evaluating others' emotions, evaluating one's own emotions, regulating emotions, social skills, use of emotions, and the total point. In the study that Sarıkabak (2020) conducted with university students who play sports, no significant result was found when the emotional intelligence levels and the emotional intelligence by gender variable and the total points of the participants were compared. According to the findings of another study, it was determined that there was no significant difference between the gender variable and the emotional intelligence averages (Azimkhani, 2014). In the literature, there are many studies in which no statistically significant difference was found between gender and emotional intelligence sub-dimensions (Erbektaş et al. 2017; Bahadır \& Adiloğulları, 2020; Yazıcı \& Güçlü, 2019; Karaoğlu et al. 2016).

Contrary to the results of this research, there are different researches which conclude that females have higher emotional intelligence levels than males (Gürbüz \& Yüksel, 2011; Güllüce \& İşcan, 2010). In a research conducted on university students, it was concluded that the emotional intelligence levels of male students were higher than female students (Ergin, 2000).

Discussion on the Years of Playing Sports Variable: It was determined that there was a low level of positive relationship between the years of playing sports of the participants and the social skills, a low level of positive relationship with the use of emotions, and that this relationship was statistically significant. This indicates that with the increase in the number of years of playing sports of the participants, the levels of social skills and use of emotions will also increase.

When the studies on the subject are examined, it is seen that there are not enough studies addressing the variable of emotional intelligence and sports age. It is seen that the studies are generally discussed according to the variables of "status of playing sports" or "playing sports as an amateur of professional". In the study, no significant relationship was found between the sports age variable and emotional intelligence (Sarıkabak, 2020). There are many studies in the literature reporting that there is no significant difference between sports status and emotional intelligence level (Kırımoğlu et al. 2014; Sarıkabak, 2018; Bahadır \& Adiloğulları, 2020; Özdinç \& Bilir, 2016).
Discussion on the Relationship Between the Scales Included in the Research: When the correlation analysis results between the emotional intelligence and mental training skills and techniques of the participants were examined, it was determined that there is a moderate level of positive correlation between evaluating others' emotions and the mental training skills and techniques total point, a moderate level between evaluating one's own emotions and mental training skills and techniques, a moderate level of positive correlation between the emotion regulation and the mental training skills and techniques, and a high level of significant positive correlation between the use of emotions and the mental training skills and techniques. This situation can be explained as the increase in the skills of evaluating one's own and others' emotions, emotion regulation and use of emotions positively affect the mental training skills and techniques. In the literature, supporting this result, it is seen that there is a positive and significant correlation between the mental skills and emotional intelligence of skiers (Azimkhani, 2014).

On the other hand, when the established multiple linear regression model was examined, the emotion regulation and use of emotions sub-dimensions were found to significantly predict the levels of mental training skills and techniques of the athletes. Accordingly, it can be said that the emotion regulation and the use of emotions are the determinants of the mental training skills and techniques. In addition, when beta coefficients were examined as a result of multiple regression analysis, the standardized regression coefficient $(\beta)$ of the emotion regulation sub-dimension was determined as .274, and the standardized regression coefficient $(\beta)$ of the use of emotions sub-dimension was determined as .486. This result, on the other hand, can be interpreted as that as the emotion regulation and the control of emotions increase, the levels of mental training skills and techniques will also increase.

\section{CONCLUSION}

As a result, when the levels of mental training skills and techniques are examined by the gender variable, it does not show any significance and it is seen that the years of playing sports and interpersonal skills of the participants show positive significance. When the emotional intelligence levels of the participants were examined by the gender variable, there was no statistically significant difference in all sub-dimensions; and when the correlation analysis results between the years of playing sports and the emotional intelligence of the participants were examined, it was determined that there was a low level of positive correlation between years of playing sports and social skills, and a low level of positive correlation with the use of emotions, and this correlation was statistically significant. When the findings of the research regarding the regression analysis were examined, it was determined that there was a positive significant correlation between all subdimensions of the emotional intelligence variable and the mental training skills and techniques. Multiple linear regression analysis was performed in order to predict the existing correlation, and it was found that the subdimensions of emotion regulation and use of emotions significantly predicted the levels of mental training skills and techniques of the athletes. 


\section{REFERENCES}

1. Arı, Ç., Ulun, C., Yarayan, Y. E., Dursun, M., Mutlu, T. \& Üstün, Ü. D. (2020). Mindfulness, healthy life skills and life satisfaction in varsity athletes and university students. Progress in Nutrition, 22(2), 1-8.

2. Adiloğulları, İ, \& Görgülü, R. (2015). The adaption study of emotional intelligence inventory in Sport. International Journal of Sports, Exercise \& Training Science - IJSETS, 8394.

3. Amasiatu, A. N. (2013). Mental imagery rehearsal as a psychological technique to enhancing sports performance. Educational Research International, 1(2): 69-77.

4. Azimkhani, A. (2014). Analyzing the Relationship among Mental Skills, Emotional Intelligence and Competition Anxiety in Young and Adult Skiers. Doctoral Thesis, Atatürk University Institute of Sports Health Sciences, Erzurum.

5. Bahadır, G, Adiloğulları, ì. (2020). The examination of relationship between mental toughness and emotional intelligence in university students engaged in sports. International Journal of Sport Exercise and Training Sciences - IJSETS, 6 (4), 117-128.

6. Behnke, M., Tomczak, M., Kaczmarak, L., Komar, M., \& Gracz, Z. (2017). The sport mental training questionnarie: development and validation. Current Psychology, 37 1-13.

7. Büyüköztürk, Ş. (2012). Sosyal bilimler için veri analizi el kitabı (16. bs.). Ankara: Pegem Akademi

8. Cohen, J. (1988). Statistical power analysis for the behavioral sciences. Hillsdale: NJ:Lawrence Erlbaum;

9. Cooper, R., \& Sawaf, A. (1997). Liderlikte duygusal zekâ: Yönetim ve organizasyonlarda duygusal zekâ (B. Ayman, Çev.). İstanbul: Sistem.

10. Creswell, J., W., \& Creswell, J. D. (2017). Research design: Qualitative, quantitative, and mixed methods approaches. Sage publications.

11. Çelik, O. B. \& Güngör, N. B. (2020). The effects of the mental training skills on the prediction of the sports sciences faculty students' anxiety levels, International Journal of Eurasian Education and Culture, Issue: 9, pp. (888-929).

12. Erbektaş, E., Üzüm, H., Özen, G., Arslan, T., Ertan, G., \& Elveren, A. (2017 An investigation of emotional intelligence of amateur and professional athletes by some variables. Journal of Abant Social Sciences. 17(4), 263-274.

13. Erdoğan, B. \& Gülşen, D. (2020). Determination of mental training levels of athletes studying in the faculty of sport sciences. Mediterranean Journal of Sport Science, 3 (1), 219-228.

14. Ergin, F. E. (2000). A research on the relationship between personality characterics and the emotional intelligence level of university student. Master Thesis, Selçuk University, Social Sciences Institute, Konya.

15. Erhan, S. E., Bedir, D., Güler, M. Ş., \& Ağduman, F. (2015). An assessment of athletic psychological skills inventory: example of Turkish development and validity. Journal of Physical Education and Sport Sciences, 17(1), 59-71.

16. Fraenkel, J. R., Wallen, N. E. \& Hyun, H. H. (2012). How to design and evaluate research in education (8. bs.). New York: McGraw-Hill.,

17. Gates, G. (1995). Review of literature on leadership and emotion: Exposing theory, posing questions, and forwarding and agenda. Journal of Leadership Studies, 2, 98-110.

18. Goleman, D. (1995). Emotional intelligence. New York: Bantam.

19. Gravetter, F. J., \& Forzano, L. A. B. (2012). Research methods for the behavioral sciences: Cengage Learning.

20. Güllüce, A. Ç. \& İşcan, Ö. F. (2010). The relationship between occupational burnout and emotional intelligence. Eskişehir Osmangazi University Journal of Economics and Administrative Sciences, October, 5(2), 7-29.

21. Gülşen, D. B. A., Yıldız, A. B., Bayköse, N. \& Eryücel, M. E. (2018). Examination of self-talks levels of individual and team sports students in the school of sports sciences according to various variables. Mediterranean Journal of Sport Science, 1(2), 58-66.

22. Gürbüz, S. \& Yüksel, M. (2008). Emotional intelligence in workplace: its relation with job performance, job satisfaction, organizational citizenship behavior, and some demographic factors. Doğuş University Journal, 9 (2), 174-190.

23. Güvendi, B. \& Pehlivan, M.Y. (2020). The examination of self-talks and aggression and anger behaviors in combat athletes, Niğde University Journal of Physical Education and Sport Sciences.14(2), 168-176.

24. Hair, J. F., Black, W. C., Babin, B. J., Anderson, R. E. \& Tatham, R. L. (2013). Multivariate data analysis. New York: Pearson Education Ltd.

25. Hardy, J., Hall, C. R. \& Hardy, L. (2005) Quantifying athlete self-talk, Journal of Sports Sciences, 23: 9, 905 - 917.

26. Kahrovic, I., Radenković, O., Mavrić, F., \& Murić, B. (2014). Effects of self-talk strategy in mental training of athletes. Facta Universitatis, Series: Physical Education and Sport, 12(1), 51-58.

27. Kara, Ö., \& Ustaoğlu Hoşver, P. (2019). Investigation of the mental training level of women volleyball player who take place in play-off competition in terms of some variables. International Sport Science Student Studies, 1(1), 35-42.

28. Karaoğlu, B., Turan, M. B., \& Pepe, O. (2016). Examination of the level of creativity and emotional intelligence level of physical education and sports students. Gaziantep University Journal of Sport Science, 1(2). 85-99.

29. Kırımoğlu, H., Yeniad, S., \& Çoban, E. (2014). Evaluation of emotional intelligence levels of candidate teachers in terms of status of playing sports (Mustafa Kemal University Sample). Gaziantep University Journal of Social Sciences, 13(1), 201-209.

30. Koçyiğit, M, Koçyiğit, A, \& Özsoy, E. (2018). The analysis of the relation between the communication skills of individuals and their stress management levels within the context of interpersonal communication: a research on national athletes. The Journal of Turkish Sport Sciences, 1 (1), 11 19.

31. Kolovelonis, A., Goudas, M., Hassandra, M. \& Dermitzaki, I. (2012). Self-regulated learning in physical education: Examining the effects of emulative and self-control practice. Psychology of Sport and Exercise, 13(4), 383-389.

32. Koruç, Z., \& Bayar, P. (1990). Mass sport and sport psychology. Sports ethics and new approaches to sports philosophy symposium, Istanbul University, Istanbul.

33. Kulak, A., Kerkez, F. İ. \& Aktaş, Y. (2011). The effects of a mental training program on motor parameters in 10-12 aged soccer players. Hacettepe Journal of Sport Sciences, 22(3): 104-114.

34. Lane, A. M., Meyer, B. M., Devenport, T. J., Davies, K. A., Thelwell, R., Gill, G. S. \& Weston, N. (2009). Validity of the emotional intelligence scale for use in sport. Journal of Sport Science and Medicine, 289-295.

35. Law, K. S., Wong, C. S., \& Song, L. J. (2004). The construct and criterion validity of emotional intelligence and its potential utility for management studies. Journal of applied Psychology, 89(3), 483.

36. Loehr, J. E. (1995). The new toughness training for sports: Mental, emotional, and physical conditioning from one of the world's premier sports psychologists. New York, NY: Plume.

37. Mizuguchi, N., Nakata, H., Uchida, Y. \& Kanosue, K. (2012). Motor imagery and sport performance. The Journal of Physical Fitness and Sports Medicine, 1(1): 103-111.

38. Nicholls, A. R., Polman, R. C., Levy, A. R. \& Backhouse, S. H. (2009). Mental toughness in sport: Achievement level, gender, age, experience, and sport type differences. Personality and Individual Differences, 47(1): 73-75. 
39. Özdinç, Ö., \& Bilir, F. P. (2016). Exploring emotional intelligence among senior sport managers. Hacettepe Journal of Sport Sciences, 27(1), 27-39.

40. Patrick, D. P. (1995). Effects of a mental training package on an endurance performance (Master of Science).

41. Sachs, M. L. (1991). Reading list in applied sport psychology: Psychological skills training. The Sport Psychologist, 5(1), 88-91

42. Salovey, P., \& Mayer, J. D. (1990). Emotional intelligence. Imagination, cognition and personality, 9(3), 185-211.

43. Sarıkabak, M. (2018). Examining social physics anxiety and emotional intelligence levels of the faculty of sport sciences students. sportive sight. Journal of Sport and Education, 7485.

44. Sarıkabak, M. (2020). Evaluation of the mental ability of the student athletes and examining their emotional intelligence levels. Revista Românească pentru Educaţie Multidimensională. 12(1), 01-19.

45. Schutte, N.S., Malouff, J.M., Hall, L.E., Haggerty, D. J., Cooper, J.T., Golden, C.J., \& Dornheim, L. (1998). Development and validation of a measure of emotional intelligence. Personality and Individual Differences, 25,167177.

46. Slimani, M., Tod, D., Chaabene, H., Miarka, B. \& Chamari, K. (2016). Effects of mental imagery on muscular strength in healthy and patient participants: A Systematic Review. Journal of Sports Science \& Medicine, 15(3): 434-450.
47. Sosik, J.J., \& Megerian, L.E. (1999). Understanding leader emotional intelligence and performance: The role of selfother agreement on transformation leadership perceptions. Group and Organization Management, 24, 367-390.

48. Tabachnick, L, \& Fidell, L, S. (2013). Using Multivariate Statistics (sixth ed.) Pearson, Boston.

49. Weinberg, R. S. \& Gould, D. S. (2014). Foundations of sport and exercise psychology. Champaign: Human Kinetics.

50. Yarayan, Y. E., \& İlhan, E. L. (2018). The sport mental training questionnaire (SMTQ) adaptation study. Gazi Journal of Physical Education and Sport Sciences, 23(4), 205-218.

51. Yarayan, Y. E., \& Ayan, S. (2018). Examination of imagination format of athletes in different team sport, International Journal of International Social Research, 11(60).

52. Yarayan, Y. E., Yıldız, A. B., \& Gülşen, D. B. A. (2018). Examination of mental toughness levels of individual and team sports players at elite level according to various variables, International Journal of International Social Research, 11(57), 992-999.

53. Yazıcı, A., \& Güçlü, M. (2019). Mental toughness and emotional intelligence of professional basketball players in terms of different variables. Lap Lambert Academic Publishing. ISBN: 978-613-9-99198-3 